\title{
A new SERS strategy for quantitative analysis of trace microalbuminuria based on immunorecognition and graphene oxide nanoribbon catalysis
}

This article was published in the following Dove Press journal:

International Journal of Nanomedicine

\author{
Guiqing Wen ${ }^{1,2, *}$ \\ Qi Jing ${ }^{1,2, *}$
}

Aihui Liang ${ }^{1,2}$

Zhiliang Jiang ${ }^{1,2}$

'Key Laboratory of Ecology of Rare and Endangered Species and Environmental Protection (Guangxi Normal University), Ministry of Education, Guangxi Key Laboratory of Environmental Pollution Control Theory and Technology, Guilin, China; ${ }^{2}$ Department of Environment Science, College of Environment and Resources, Guangxi Normal University, Guilin, China

*These authors contributed equally to this work
Correspondence: Aihui Liang; Zhiliang Jiang

College of Environment and Resources, Guangxi Normal University, 15 Yucai

Road, Guilin 541004, China

Email ahliang2008@163.com;

zljiang@mailbox.gxnu.edu.cn
Background: Microalbuminuria (mAlb) detection is essential for the diagnosis and prognosis of nephrotic patients and hypoproteinemia. In this article, we develop a new surface-enhanced Raman scattering (SERS) quantitative analysis method to detect mAlb in urine.

Methods: Combined the mAlb immunoreaction with gold nanoreaction of graphene oxide nanoribbons (GONR)-HAuCl $-\mathrm{H}_{2} \mathrm{O}_{2}$, and used Victoria blue $\mathrm{B}$ (VBB) as molecular probe with a SERS peak at $1,615 \mathrm{~cm}^{-1}$, a new SERS strategy for quantitative analysis of trace mAlb in urine was established.

Results: The linear range of SERS quantitative analysis method is from 0.065 to $2.62 \mathrm{ng} / \mathrm{mL}$, with a detection limit of $0.02 \mathrm{ng} / \mathrm{mL}$. The SERS method was applied to analysis of $\mathrm{mAlb}$ in urine with good accuracy and reliability, the relative standard deviation is $0.49 \%-2.28 \%$ and the recovery is $96.9 \%-109.8 \%$.

Conclusion: This study demonstrated that the new SERS quantitative analysis method is of high sensitivity, good selectivity and simplicity. It has been applied to analysis of mAlb in urine, with satisfactory results.

Keywords: graphene oxide nanoribbon, nanocatalysis, microalbumin immunoreaction, gold nanoreaction, SERS

\section{Introduction}

Nanoparticles in solutions not only have novel surface nanoplasmon effect but also exhibit high catalytic activity as natural enzymes and mimic enzymes with stabilization and economic characteristics, and it has been used in different fields such as materials science, physics, chemistry, biology, and environmental science. ${ }^{1-4}$ In analytical chemistry, catalysis such as molecular reaction and nanoparticle reaction can be used to amplify signals to enhance sensitivity and have been utilized in absorption, fluorescence, resonance Rayleigh scattering (RRS), and surface-enhanced Raman scattering (SERS). ${ }^{5-8}$ A label-free DNAzyme-cleaving fluorescence method was developed for the determination of trace $\mathrm{Pb}^{2+}$ based on the catalysis of AuPd nanoalloy on the reduction of rhodamine $6 \mathrm{G} .{ }^{5} \mathrm{Qu}$ et al reported a colorimetric platform for visual detection of $0.1-10 \mathrm{ng} / \mathrm{mL}$ cancer biomarker based on intrinsic peroxidase activity of graphene oxide (GO). ${ }^{6}$ He et al prepared Au@Pt nanorods, which showed multiple enzyme properties and were used for spectrophotometric determination of $4.5 \times 10^{-5}-1 \times 10^{-3} \mathrm{~mol} / \mathrm{L}$ glucose $(\mathrm{Glu}) .^{7}$ The nanocatalytic particle reaction is very interesting due to the novel surface plasmon resonance of $\mathrm{Au}$ and $\mathrm{Ag}$ nanoparticle that can be utilized to develop surface plasmon resonance absorption, RRS, and SERS methods with good features. A facile and sensitive peptide-modulating GONR catalytic nanoplasmon analytical 
platform was reported for human chorionic gonadotropin. ${ }^{8}$ Recently, non-metal nanoparticles are interesting to analysts. Carbon nanotube (CNT) is a one-dimensional nanomaterial with a complete molecular structure at the nanoscale and is a good precursor to prepare water-soluble and stable GONR. CNTs have been used in the field of chemical sensing for its excellent physical and chemical properties. Ye et $\mathrm{al}^{9}$ produced $\mathrm{MnO}_{2} / \mathrm{CNT}$ composites with $\mathrm{KMnO}_{4}$ oxidizing multi-walled carbon nanotubes (MWCNTs) to have strong electrocatalytic oxidation properties to detect $\mathrm{H}_{2} \mathrm{O}_{2}$ as low as $0.1 \mu \mathrm{M}$. Qu et al ${ }^{10}$ investigated the catalytic activity of the peroxidase mimetics of single-walled carbon nanotubes (SWCNTs) and achieved the $\mathrm{Cu}^{2+}$ visual detection. Cui et al ${ }^{11}$ prepared helical CNTs by hydrothermal-hydrogen reduction and investigated its catalytic activity as peroxidase mimetics. An electrochemical biosensor for $\mathrm{H}_{2} \mathrm{O}_{2}$ was developed with a linear range (LR) of $0.5-115 \mu \mathrm{mol} / \mathrm{L}$. Zhang et $\mathrm{al}^{12}$ formed composite nanomaterials by combining positively charged gold nanoparticles (AuNPs) with SWCNTs and found that the material had a strong peroxide mimetic enzyme activity, thereby established a labeled DNA hybridization colorimetric detection method. However, CNTs are not water soluble that limits its application, and GONRs overcome this problem and provide the conditions for its analytical application without organic solvents. Zhang ${ }^{13}$ developed a bioelectrochemical sensor based on GONR modified for rapid detection of $\mathrm{L} / \mathrm{D}$-amino acids (AA) with an $\mathrm{LR}$ of $0.25-1.25 \mathrm{mmol} / \mathrm{L}$ and a detection limit (DL) of 100 and $60 \mu \mathrm{mol} / \mathrm{L}$, respectively. Dong et al ${ }^{14}$ used GONR to build biosensors to detect $5-100 \mu \mathrm{mol} / \mathrm{L}$ adenosine triphosphate. Zhu et al ${ }^{15}$ developed a novel MWCNTs@GONR core-shell heterostructure and a sensitive electrochemical sensor for the detection of 8-500 nmol/L polycyclic aromatic amines. So far, no SERS was used to track GONR-catalytic AuNP reaction that can be regulated by $\mathrm{mAlb}$ immunoreaction for assay of trace mAlb.

SERS is a kind of selective and sensitive molecular spectral technique, which has attracted much attention in analysis, biology, and medical treatment. ${ }^{16}$ Generally, SERS signal depends upon a number of factors. However, the substrateadsorbed molecular probe can greatly amplify the signals and it is linear to the SERS signal at some certain conditions, ${ }^{17,18}$ and an SERS method can be developed for the detection of the molecular probe. Javier and Ronei ${ }^{17}$ studied a paper-based portable SERS method for the detection of uric acid, with an LR of $0-3.5 \mathrm{mmol} / \mathrm{L}$ and a DL of $0.11 \mathrm{mmol} / \mathrm{L}$. Wang et $\mathrm{al}^{18}$ used the catalytic activity of $\mathrm{GO}$ to catalyze the $\mathrm{H}_{2} \mathrm{O}_{2}-\mathrm{HAuCl}_{4}$ system, and then ligands regulated the use of SERS to detect human chorionic gonadotropin, and $\mathrm{Hg}^{2+}$ in concentrations ranging from 0.25 to $10 \mathrm{ng} / \mathrm{mL}, 0.25-10 \mathrm{nmol} / \mathrm{L}$, was tested on samples which showed good recovery. Frost et al ${ }^{19}$ developed a SERS sensor based on citrate-functionalized AuNP for $50-1,000 \mathrm{ng} / \mathrm{L} \mathrm{Pb}^{2+}$. Gao et $\mathrm{al}^{20}$ immobilized the peptide nucleic acid with the target DNA on a slide, and $1.0 \times 10^{-10}-1.0 \times 10^{-6} \mathrm{~mol} / \mathrm{L}$ DNA can be detected by SERS. Another type of SERS method was reported according to the change in the concentration of nanosol substrate in the analytical system. For example, a facile aptamer-regulating gold nanoplasmonic SERS detection strategy was proposed for trace lead ions based on the nanocatalytic particle reaction and nanoplasmon. Immunoassay is a kind of analytical method based on the specific reaction of antigen and antibody (Ab). It has the characteristics of high sensitivity and specificity and has been used in the fields of disease diagnosis, food safety, and environmental protection. ${ }^{21}$ In recent years, highly sensitive SERS technology combining with specific immunoreaction has been favored to analysts. ${ }^{22-26} \mathrm{Ma}$ et al ${ }^{26}$ reported an SERS quantitative analysis method for trace human chorionic gonadotropin using a label-free Victoria blue $\mathrm{B}$ (VBB; $\mathrm{C}_{33} \mathrm{H}_{32} \mathrm{ClN}_{3}$ ) as probe in the aggregated immunonanogold sol substrate. She et $\mathrm{al}^{27}$ combined $\mathrm{Hg}^{2+}$ with the double-labeled Raman active 4-mercaptobenzoic acid and gold nanoparticles monoclonal antibodies on immunochromatographic test strips to obtain SERS immunoprobe to detect as low as $0.45 \mathrm{pg} / \mathrm{mL}$ of $\mathrm{Hg}^{2+}$. To our best knowledge, there are no SERS quantitative analysis methods for trace $\mathrm{mAlb}$ without preparation of immunonanoprobe and label-free SERS molecular probes, based on the coupling of GONR-catalytic nanoreaction with immunoreaction.

Albumin is a normal protein in the blood, but there is only a small amount of albumin in the urine under physiological conditions $(<20 \mathrm{mg} / \mathrm{L})$, because it is usually reabsorbed by glomerular filtration and renal proximal tubule. ${ }^{28}$ Urinary albumin that is normally in the range of $20-200 \mathrm{mg} / \mathrm{L}$ is called as microalbuminuria (mAlb). ${ }^{29}$ So it should be noted when the mAlb concentration is sustained excess, because it shows that nephrotic patients have a large number of albumin leakage and may be hypoproteinemia. And the development of kidney disease is possibly irreversible. Therefore, proteinuria is an important clinical symptom of nephropathy, and the control of mAlb concentration has a great clinical reference value to determine the degree of disease and prognosis. The rise of mAlb concentration is a reflection of early glomerular lesions sensitive indicators, especially in chronic renal injury such as diabetic nephropathy, hypertension, and systemic lupus erythematosus, and its detection is clinically significant. ${ }^{30}$ At present, mAlb detection methods are mainly electrochemical immunosensor, ${ }^{31}$ 
radioimmunoassay, ${ }^{32}$ ELISA, ${ }^{33}$ turbidity analysis,,${ }^{34}$ highperformance liquid chromatography, and so on. ${ }^{35}$ In this paper, a new gold nanoplasmon molecular spectral platform was established for rapid and selective quantitative detection of trace mAlb based on the immunoreaction-regulation of the GONR catalytic AuNP reaction.

\section{Experimental}

\section{Instruments and reagents}

A DXR smart Raman spectrometer (Thermo Fisher Scientific, Waltham, MA, USA) with laser wavelength of $633 \mathrm{~nm}$, power of $2.5 \mathrm{~mW}$, slit of $50 \mu \mathrm{m}$, and acquisition time of 5 seconds; Hitachi F-7000 fluorescence spectrophotometer (Hitachi Ltd, Tokyo, Japan); TU-1901 dual-beam UV-visible spectrophotometer (Beijing Puxi General Equipment Limited Company, Beijing, China); and constant temperature water bath were used.

A $97 \mathrm{mmol} / \mathrm{L} \mathrm{HAuCl}_{4}$ solution, $10 \mu \mathrm{mol} / \mathrm{L} \mathrm{VBB}, 10 \mathrm{~mol} / \mathrm{L}$ $\mathrm{H}_{2} \mathrm{O}_{2}$ solution, $3.4 \mathrm{mmoL} / \mathrm{L}$ trisodium citrate, $10 \mathrm{mmol} / \mathrm{L}$ $\mathrm{AgNO}_{3}, 0.1 \mathrm{moL} / \mathrm{L} \mathrm{Glu}, 10 \mathrm{mg} / \mathrm{mL} \mathrm{mAlb}$, and $5 \mathrm{mg} / \mathrm{mL} \mathrm{mAlb}$ $\mathrm{Ab}$ were prepared. 98\% $\mathrm{H}_{2} \mathrm{SO}_{4}, \mathrm{KMnO}_{4}$, GO (Nanjing Xianfeng Nanomaterial Technology Co. Ltd, Nanjing, China) and MWCNTs (No XFM12; Nanjing Xianfeng Nanomaterial Technology Co. Ltd) were used. The used reagents were of analytical pure grade, and the experimental water was the secondary distilled water.

\section{Preparation of GONR}

GONR was prepared by chemical melting MWCNTs. $50 \mathrm{mg}$ of MWCNT powder was added into a $50 \mathrm{~mL}$ round bottom flask which containing $10 \mathrm{~mL}$ of concentrated $\mathrm{H}_{2} \mathrm{SO}_{4}$ and the reaction took place for 1 hour. Then, a certain content $(100,200,250,300,400,500,750$, or $1,000 \mathrm{mg})$ of $\mathrm{KMnO}_{4}$ was added and mixed well before the solution being heated for 2 hours in a $60^{\circ} \mathrm{C}$ water bath. The product was added into $200 \mathrm{~mL}$ ice water containing $5 \mathrm{~mL}$ of $30 \% \mathrm{H}_{2} \mathrm{O}_{2}$ before being dispersed for 10 minutes by unltrasonic and centrifuged at 7,000 rpm for 10 minutes. The supernatant was obtained which contained $230 \mu \mathrm{g} / \mathrm{mL}$ GONR. Thus, GONR of different oxidation degrees (GONR1, GONR2, GONR3, GONR4, GONR5, GONR6, GONR7, and GONR8) were prepared by changing the amount of $\mathrm{KMnO}_{4}$. The supernatant was neutralized to $\mathrm{pH} 7$ with $50 \mathrm{mmol} / \mathrm{L} \mathrm{NaOH}$ and diluted to the desired concentration before use.

\section{Procedure}

A suitable concentration of $\mathrm{mAlb}, 50 \mu \mathrm{L}$ of $60 \mathrm{ng} / \mathrm{mL} \mathrm{mAlb}$ and $60 \mu \mathrm{L}$ of $47.6 \mathrm{ng} / \mathrm{mL}$ GONR were added into a $5 \mathrm{~mL}$ test tube successively. After mixing well for 10 minutes, $100 \mu \mathrm{L}$ of $2.9 \mathrm{mmol} / \mathrm{L} \mathrm{HAuCl}_{4}$ and $30 \mu \mathrm{L}$ of $0.1 \mathrm{~mol} / \mathrm{L} \mathrm{H}_{2} \mathrm{O}_{2}$ solution were added and diluted to the volume of $1.5 \mathrm{~mL}$ with water. The mixture was heated in a $60^{\circ} \mathrm{C}$ water bath for 10 minutes, then cooled with ice water to terminate the reaction, and $50 \mu \mathrm{L}$ $10 \mu \mathrm{mol} / \mathrm{L}$ VBB was added. The SERS intensity $\left(\mathrm{I}_{1,615 \mathrm{~cm}^{-1}}\right)$ and the blank without $\mathrm{mAlb}\left(\mathrm{I}_{1,615 \mathrm{~cm}^{-1}}\right)_{0}$ was measured to calculate the value of $\Delta \mathrm{I}_{1,615 \mathrm{~cm}^{-1}}=\mathrm{I}_{1,615 \mathrm{~cm}^{-1}}-\left(\mathrm{I}_{1,615 \mathrm{~cm}^{-1}}\right)_{0}$. DL was three times of SD which obtained from parallel determination of blank samples $(\mathrm{n}=10)$.

\section{Results and discussion Principles of analysis}

The catalytic reaction of $\mathrm{H}_{2} \mathrm{O}_{2}-\mathrm{HAuCl}_{4}$ increased with the increase of GONR concentration. The more the nanoparticle catalyst is added, the higher SERS intensity is obtained. In the system with $\mathrm{Ab}$, the protein macromolecules bound to GONR and inhibited its catalytic activity. When the mAlb antigen was added, it specifically bound to the $\mathrm{Ab}$, and the nanoenzyme GONR was released. With the increase of the amount of $\mathrm{mAlb}$, the SERS peak increased due to the restoration of GONR catalysis. The mAlb concentration and SERS peak were of a linear relationship, which could be established to detect $\mathrm{mAlb}$ by SERS technique (Figure 1).

\section{SERS spectra}

Under the normal pressure and temperature, the reaction of $\mathrm{H}_{2} \mathrm{O}_{2}$ and $\mathrm{HAuCl}_{4}$ was slow. GONR had strong catalytic effect on the reaction to form AuNPs that exhibited five strong SERS peaks in the presence of VBB molecular probes. The characteristic peaks of the above system include 1,164 (C-C stretching), 1,199 (C-H bending), 1,362 (ring stretching), 1,393 (C-N stretching), and 1,615 ( $\mathrm{C}=\mathrm{N}$ and $\mathrm{N}-\mathrm{H}$ stretching). After adding $\mathrm{Ab}$, it could inhibit the catalytic activity of GONR by binding to the surface of GONR catalyst, and the SERS signal linearly decreased (Figure S1). After the addition of $\mathrm{mAlb}$, the stable immunocomplexes formed to release free GONR, and the SERS signal enhanced due to the catalysis recovering. With the increase of the amount of mAlb, the catalysis increased to cause the SERS intensity to gradually increase for the GONR6 (Figure 2), GONR3 (Figure S2A), and GO (Figure S2B) analytical systems. Results showed that the GONR6 catalysis, using the slope of $\mathrm{I}_{1,615 \mathrm{~cm}^{-1}}$ vs concentration of GONR, was the strongest, and the GONR6 system for detection of mAlb was the most sensitive. The blank spectra of pure GONRs, antibodies, and micro-albumin of the test concentrations were recorded respectively, and the results showed that all the blank spectra were very weak and that meant that the SERS peaks mainly attributed to the product of the nanocatalytic reaction. The SERS peak at $1,615 \mathrm{~cm}^{-1}$ 

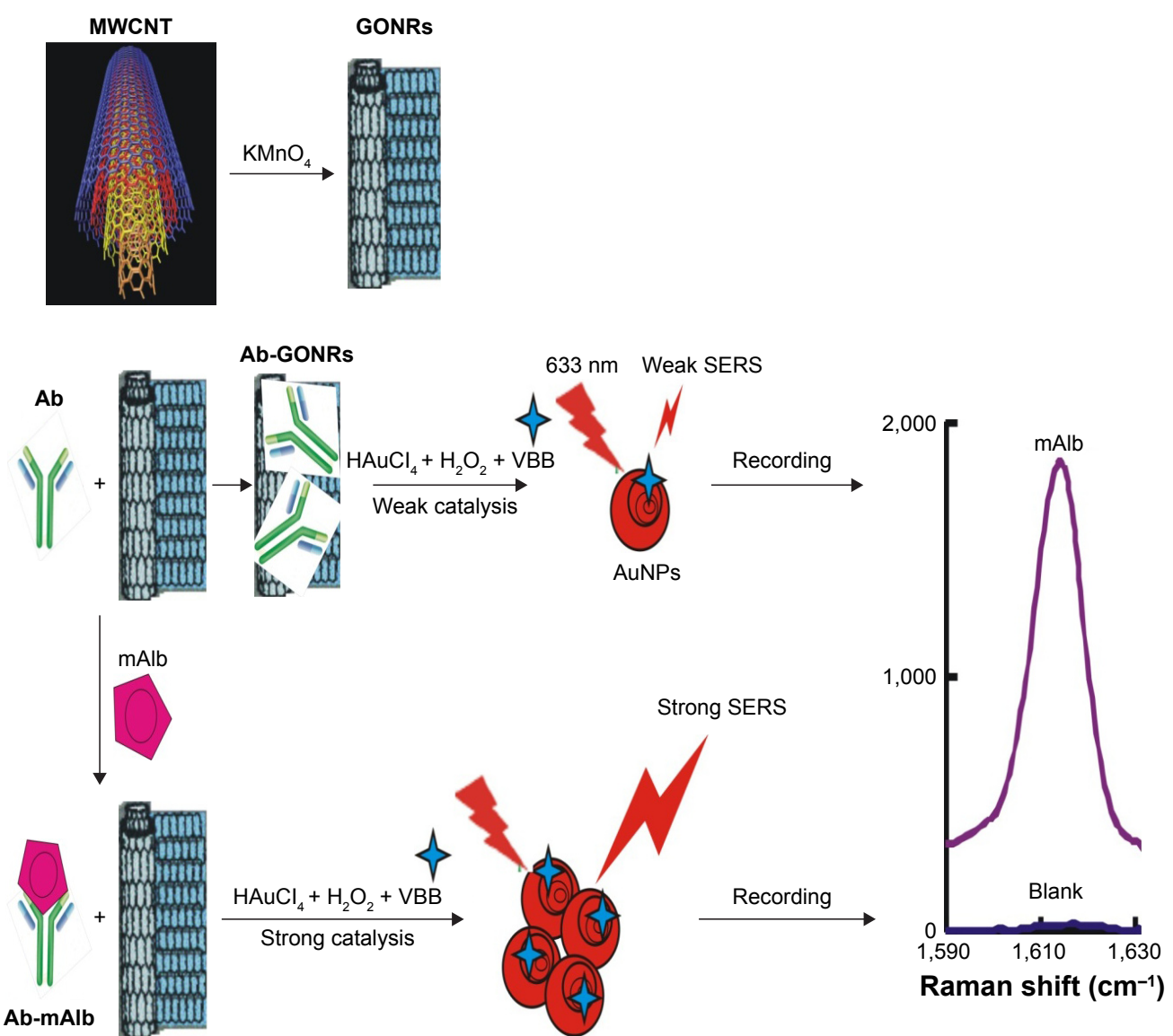

Figure I Principles of SERS immunoanalysis of mAlb coupled with GONR catalysis.

Abbreviations: SERS, surface-enhanced Raman scattering; GONR, graphene oxide nanoribbon; VBB, Victoria blue B; Ab, antibody; mAlb, microalbumin; MWCNT, multi-walled carbon nanotube.

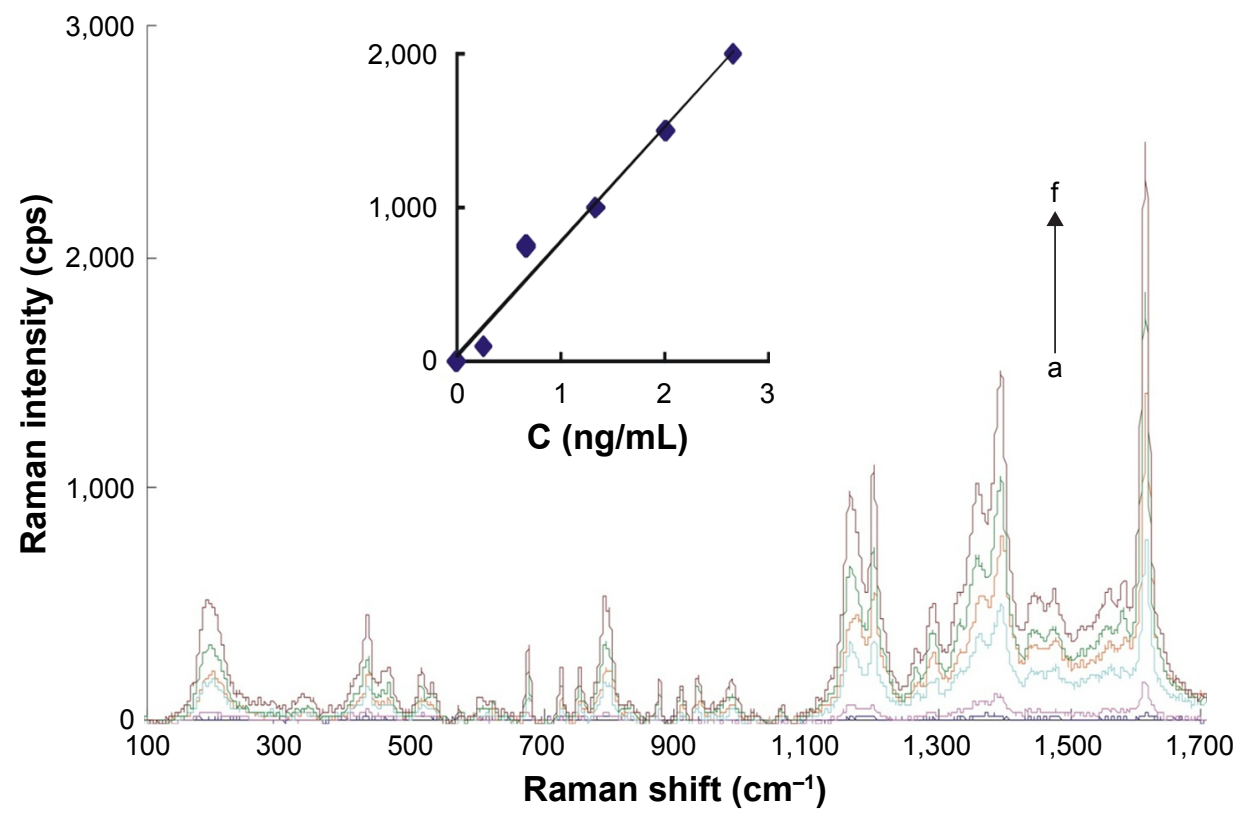

Figure 2 SERS spectra of GONR6-Ab-mAlb- $\mathrm{HAuCl}_{4}-\mathrm{H}_{2} \mathrm{O}_{2}$.

Notes: a: $0.21 \mathrm{mmol} / \mathrm{L} \mathrm{HAuCl}{ }_{4}+0.006 \% \mathrm{H}_{2} \mathrm{O}_{2}+2.34 \mathrm{ng} / \mathrm{mL} \mathrm{GONR} 6+0.1 \mathrm{mmol} / \mathrm{L} \mathrm{HCl}+3.3 \times 10^{-7} \mathrm{~mol} / \mathrm{L} \mathrm{VBB}+3.3 \mathrm{ng} / \mathrm{mL} \mathrm{Ab;} \mathrm{b:} \mathrm{a}+0.26 \mathrm{ng} / \mathrm{mL} \mathrm{mAlb} ; \mathrm{c}: \mathrm{a}+0.665 \mathrm{ng} / \mathrm{mL}$ $\mathrm{mAlb}$; $\mathrm{d}$ a $+1.33 \mathrm{ng} / \mathrm{mL} \mathrm{mAlb}$; e: a $2 \mathrm{ng} / \mathrm{mL} \mathrm{mAlb} ; \mathrm{f}: \mathrm{a}+2.62 \mathrm{ng} / \mathrm{mL} \mathrm{mAlb}$.

Abbreviations: SERS, surface-enhanced Raman scattering; GONR, graphene oxide nanoribbon; Ab, antibody; mAlb, microalbumin; VBB, Victoria blue B. 
was chosen for mAlb assay because it was the most sensitive and the intensity $\Delta \mathrm{I}_{1,615 \mathrm{~cm}^{-1}}=\mathrm{I}_{1,615 \mathrm{~cm}^{-1}}-\left(\mathrm{I}_{1,615 \mathrm{~cm}^{-1}}\right)_{0}$ was linear to the $\mathrm{mAlb}$ concentration.

\section{RRS and UV-Vis spectra}

According to the procedure, the RRS spectra were obtained by synchronous scanning with the fluorescence spectrophotometer under the conditions of voltage $=450 \mathrm{~V}$, excited slit $=$ emission slit $=5 \mathrm{~nm}$, emission filter $=1 \% \mathrm{~T}$ attenuator, and $\lambda_{\mathrm{ex}}-\lambda_{\mathrm{em}}=\Delta \lambda=0$. The results showed that GONR had a strong resonance scattering peak at about $310 \mathrm{~nm}$. With the increase of $\mathrm{mAlb}$ concentration, more GONR was released and more AuNPs were produced which lead to the linear increase in the RRS peak (Figure S3). In the GONR systems, GONR6 was the most sensitive, and a simple and sensitive RRS method could also be developed to detect the concentrations of mAlb with an LR of $0.08-3.18 \mathrm{ng} / \mathrm{mL}$ (Figure $3 \mathrm{~A}$ ). Compared to the SERS method, the RRS method was less sensitive, but the procedure of RRS method is simpler than the SERS method without VBB. The TU-1901 dual-beam

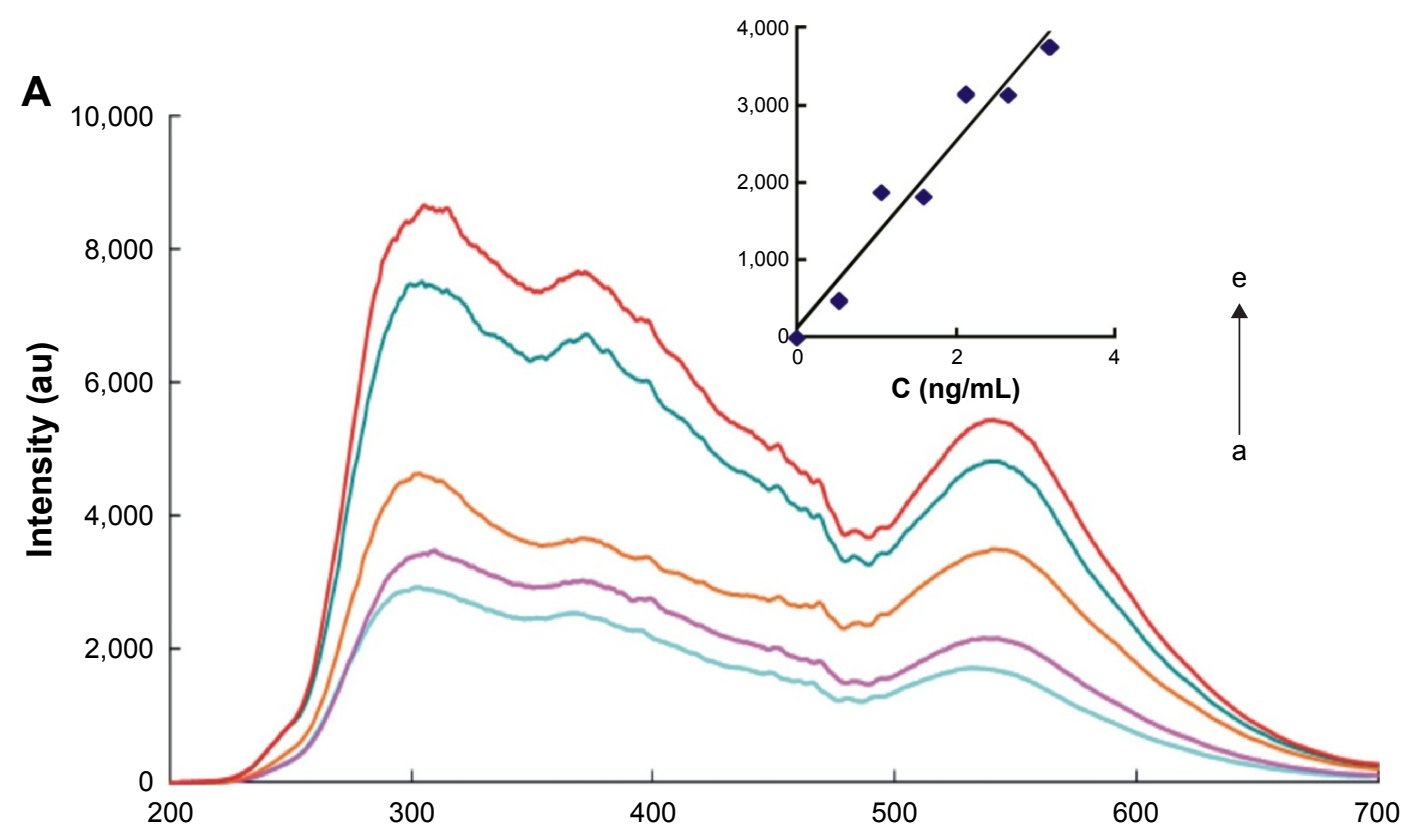

B

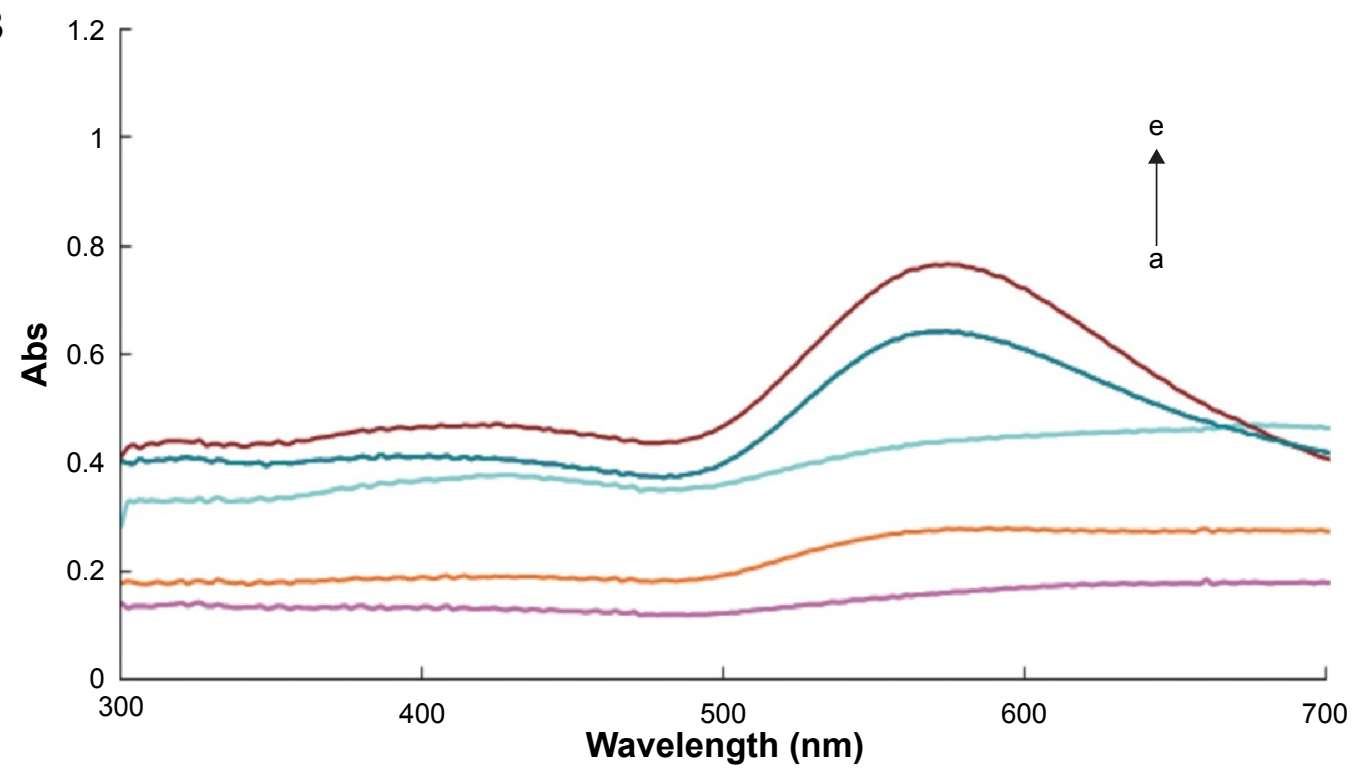

Figure 3 RRS and absorption spectra of GONR6-Ab-mAlb- $-\mathrm{HAuCl}_{4}-\mathrm{H}_{2} \mathrm{O}_{2}$.

Notes: (A) a: $0.21 \mathrm{mmol} / \mathrm{L} \mathrm{HAuCl}_{4}+0.006 \% \mathrm{H}_{2} \mathrm{O}_{2}+2.34 \mathrm{ng} / \mathrm{mL} \mathrm{GONR6}+3.3 \times 10^{-7} \mathrm{~mol} / \mathrm{L} \mathrm{VBB}+3.3 \mathrm{ng} / \mathrm{mL} \mathrm{Ab;} \mathrm{b:} \mathrm{a}+0.53 \mathrm{ng} / \mathrm{mL} \mathrm{mAlb} ; \mathrm{c}: \mathrm{a}+\mathrm{I} .06 \mathrm{ng} / \mathrm{mL} \mathrm{mAlb} ; \mathrm{d}: \mathrm{a}+$ $2.12 \mathrm{ng} / \mathrm{mL} \mathrm{mAlb}$; e: a $+2.65 \mathrm{ng} / \mathrm{mL} \mathrm{mAlb}$. (B) a: $0.21 \mathrm{mmol} / \mathrm{L} \mathrm{HAuCl}{ }_{4}+0.006 \% \mathrm{H}_{2} \mathrm{O}_{2}+2.34 \mathrm{ng} / \mathrm{mL} \mathrm{GONR6}+3.3 \times 10^{-7} \mathrm{~mol} / \mathrm{L} \mathrm{VBB}+3.3 \mathrm{ng} / \mathrm{mL} \mathrm{Ab;} \mathrm{b:} \mathrm{a}+0.53 \mathrm{ng} / \mathrm{mL} \mathrm{mAlb}$; c: a + $1.59 \mathrm{ng} / \mathrm{mL}$ mAlb; d: a $+2.12 \mathrm{ng} / \mathrm{mL} \mathrm{mAlb} ;$ e: a $+2.65 \mathrm{ng} / \mathrm{mL} \mathrm{mAlb}$.

Abbreviations: RRS, Rayleigh scattering; GONR, graphene oxide nanoribbon; Ab, antibody; mAlb, microalbumin; VBB, Victoria blue B. 


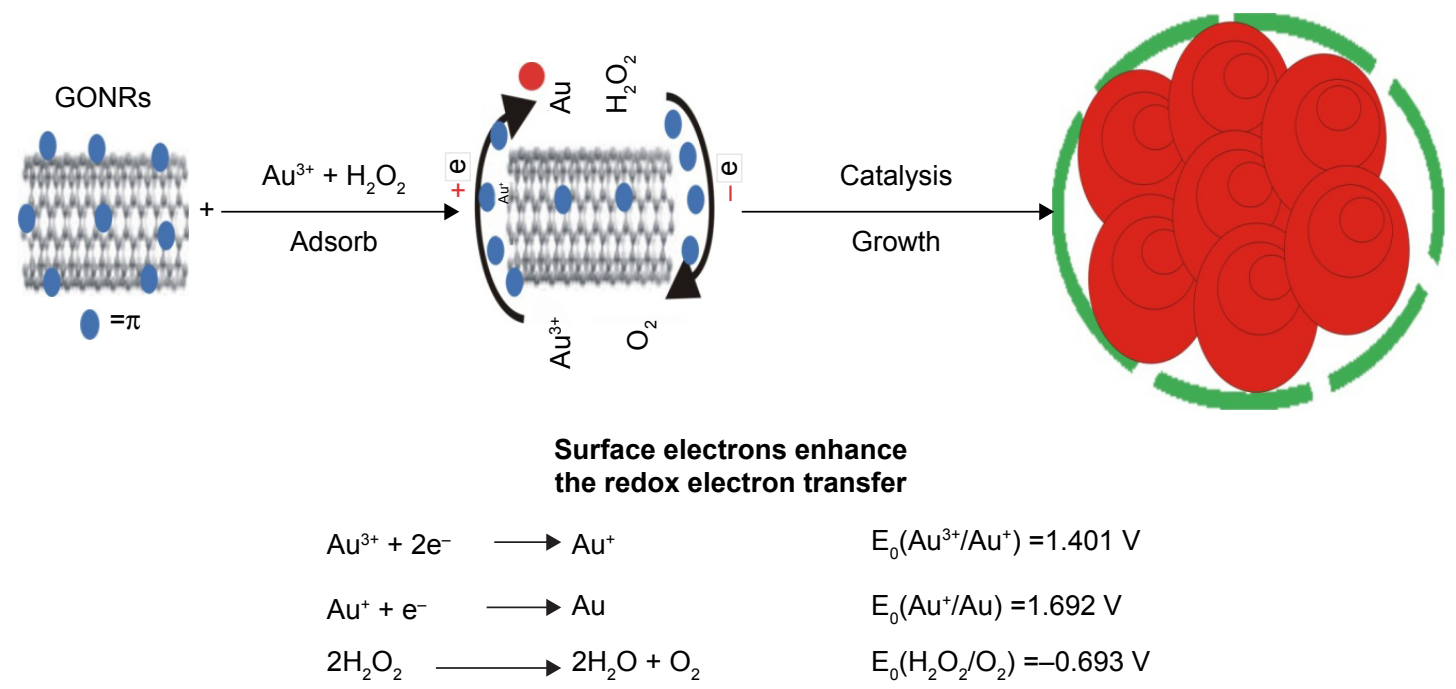

Figure 4 Mechanism of GONR catalyzed $\mathrm{H}_{2} \mathrm{O}_{2}$ reduction of $\mathrm{HAuCl}_{4}$ to produce nanogold particles.

Abbreviation: GONR, graphene oxide nanoribbon.

UV-Vis spectrophotometer was used to measure the absorbance of the system, and the results (Figure 3B, Figure S4) showed that GONR6 system had an obvious absorption peak at about $580 \mathrm{~nm}$. With the increase of mAlb concentration, the Abs peak gradually increased.

\section{Catalysis and inhibition}

Under the experimental conditions, MWCNT has no catalysis because it is insoluble in water. GONR and GO catalyzed $\mathrm{H}_{2} \mathrm{O}_{2}-\mathrm{HAuCl}_{4}$ reaction to generate nanoparticles (Figure 4). As the oxidation-reduction pair of $\mathrm{Au}^{3+} / \mathrm{Au}$ has a low potential $(1.401 \mathrm{~V}),{ }^{36}$ it is difficult to form AuNPs from the $\mathrm{Au}^{3+}$ ions in one step. The reaction is easier to proceed with the addition of GONR as a catalyst. Since GONR has rich surface electrons, the electrons are transferred from the GONR to the $\mathrm{Au}^{3+}$ ions and converted into $\mathrm{Au}^{+}$ions. The oxidation-reduction pair of $\mathrm{Au}^{+} / \mathrm{Au}$ has higher potential (1.692 V) and AuNPs are easier to be obtained. The catalytic activities of eight kinds of different GONR were compared mainly by three parameters (LR, linear equation, and coefficient), and the inhibition of Ab was studied (Table 1). The results showed that the linear equation of GONR6 system had

Table I Comparison of catalysis and Ab inhibition by SERS method

\begin{tabular}{|c|c|c|c|}
\hline Catalysis system & Linear range & Linear equation & Coefficient \\
\hline GONRI & $0.91-3.06 \mathrm{ng} / \mathrm{mL}$ GONRI & $\Delta \mathrm{I}_{1615 \mathrm{~cm}^{-1}}=120.01 \mathrm{C}+4.5$ & 0.9321 \\
\hline GONR2 & $0.91-3.06 \mathrm{ng} / \mathrm{mL}$ GONR2 & $\Delta \mathrm{l}_{\mathrm{l}, 615 \mathrm{~cm}^{-1}}=198.4 \mathrm{C}-32 . \mathrm{I}$ & 0.9643 \\
\hline GONR3 & $0.9 \mathrm{I}-3.06 \mathrm{ng} / \mathrm{mL}$ GONR3 & $\Delta \mathrm{l}_{\mathrm{l}, 615 \mathrm{~cm}^{-1}}=346.0 \mathrm{C}-139.2$ & 0.9537 \\
\hline GONR4 & $0.9 \mathrm{I}-3.06 \mathrm{ng} / \mathrm{mL}$ GONR4 & $\Delta \mathrm{l}_{\mathrm{l}, 615 \mathrm{~cm}^{-1}}=412.7 \mathrm{C}-90.9$ & 0.9293 \\
\hline GONR5 & $0.91-3.06 \mathrm{ng} / \mathrm{mL}$ GONR5 & $\Delta \mathrm{I}_{\mathrm{l}, 615 \mathrm{~cm}^{-1}}=437.6 \mathrm{C}-137.3$ & 0.9551 \\
\hline GONR6 & $0.9 \mathrm{I}-3.06 \mathrm{ng} / \mathrm{mL}$ GONR6 & $\Delta \mathrm{I}_{\mathrm{l}, 615 \mathrm{~cm}^{-1}}=782.5 \mathrm{C}-27 \mathrm{I} .5$ & 0.9458 \\
\hline GONR7 & $0.91-3.06 \mathrm{ng} / \mathrm{mL}$ GONR7 & $\Delta \mathrm{l}_{\mathrm{l}, 615 \mathrm{~cm}^{-1}}=428.9 \mathrm{C}-7 \mathrm{I} .7$ & 0.9689 \\
\hline GONR8 & $0.91-3.06 \mathrm{ng} / \mathrm{mL}$ GONR8 & $\Delta \mathrm{l}_{\mathrm{l}, 615 \mathrm{~cm}^{-1}}=275.3 \mathrm{C}-52.0$ & 0.9644 \\
\hline Ab-GONRI & $0.26-5.3 \mathrm{ng} / \mathrm{mL} \mathrm{Ab}$ & $\Delta \mathrm{I}_{\mathrm{l}, 615 \mathrm{~cm}^{-1}}=60.8 \mathrm{C}+61.8$ & 0.904 \\
\hline Ab-GONR2 & $0.26-5.3 \mathrm{ng} / \mathrm{mL} \mathrm{Ab}$ & $\Delta \mathrm{l}_{\mathrm{l}, 615 \mathrm{~cm}-1}=94.5 \mathrm{C}+85.3$ & 0.9356 \\
\hline Ab-GONR3 & $0.26-5.3 \mathrm{ng} / \mathrm{mL} \mathrm{Ab}$ & $\Delta \mathrm{l}_{1,615 \mathrm{~cm}^{-1}}=161.0 \mathrm{C}+60.7$ & 0.9562 \\
\hline Ab-GONR4 & $0.26-5.3 \mathrm{ng} / \mathrm{mL} \mathrm{Ab}$ & $\Delta \mathrm{l}_{1,615 \mathrm{~cm}^{-1}}=174.7 \mathrm{C}+33.2$ & 0.9764 \\
\hline Ab-GONR5 & $0.26-5.3 \mathrm{ng} / \mathrm{mL} \mathrm{Ab}$ & $\Delta \mathrm{l}_{\mathrm{l}, 615 \mathrm{~cm}^{-1}}=197 \mathrm{C}+153.0$ & 0.929 \\
\hline Ab-GONR6 & $0.26-5.3 \mathrm{ng} / \mathrm{mL} \mathrm{Ab}$ & $\Delta \mathrm{I}_{1,615 \mathrm{~cm}^{-1}}=363.5 \mathrm{C}-51 \mathrm{I} .8$ & 0.9776 \\
\hline Ab-GONR7 & $0.26-5.3 \mathrm{ng} / \mathrm{mL} \mathrm{Ab}$ & $\Delta \mathrm{I}_{\mathrm{l}, 615 \mathrm{~cm}^{-1}}=206.8 \mathrm{C}+160.5$ & 0.9339 \\
\hline Ab-GONR8 & $0.26-5.3 \mathrm{ng} / \mathrm{mL} \mathrm{Ab}$ & $\Delta \mathrm{I}_{\mathrm{l}, 615 \mathrm{~cm}^{-1}}=130.2 \mathrm{C}+\mathrm{I} \mid 3.2$ & 0.9204 \\
\hline
\end{tabular}

Abbreviations: Ab, antibody; GONR, graphene oxide nanoribbon; SERS, surface-enhanced Raman scattering. 


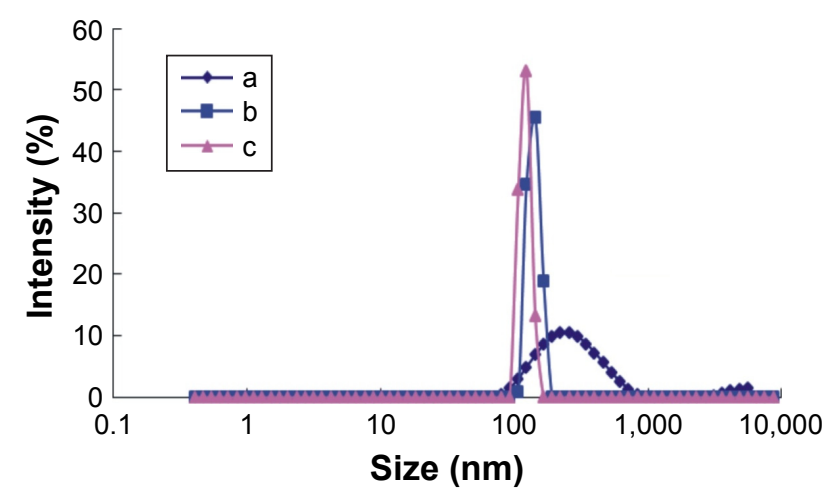

Figure 5 Distribution of size of the nanoparticles.

Notes: a: $0.21 \mathrm{mmol} / \mathrm{L} \mathrm{HAuCl}_{4}+0.006 \% \mathrm{H}_{2} \mathrm{O}_{2}+1.84 \mathrm{ng} / \mathrm{mL} \mathrm{GONR6}+3.3 \mathrm{ng} / \mathrm{mL}$ Ab; b: a + $1.33 \mathrm{ng} / \mathrm{mL} \mathrm{mAlb}$; c: a $+3.2 \mathrm{ng} / \mathrm{mL} \mathrm{mAlb}$.

Abbreviations: Ab, antibody; GONR, graphene oxide nanoribbon; mAlb, microalbumin.

the highest slope. This shows that GONR6 had the strongest catalysis because MWCNT had the most suitable oxidation degree and the carboxyl numbers were the most suitable. When the $\mathrm{Ab}$ was added into the system, the $\mathrm{Ab}$ would attach to the GONR surface, blocking the contact between the catalyst and $\mathrm{H}_{2} \mathrm{O}_{2} / \mathrm{HAuCl}_{4}$ to inhibit its catalytic activity. With the increase of $\mathrm{Ab}$, the system catalytic effect reduced and the SERS intensity weakened. The system reduction $\Delta \mathrm{I}_{1,615 \mathrm{~cm}^{-1}}$ has a linear relationship with $\mathrm{Ab}$ concentration, and the inhibition of Ab-GONR6 system was the strongest because the slope is biggest.

\section{Laser scattering}

The size distribution of nanoparticles of mAlb-Ab-GONR6$\mathrm{H}_{2} \mathrm{O}_{2}-\mathrm{HAuCl}_{4}$ system was detected (Figure 5). The results showed that the average particle size of the non-mAlb system was $240 \pm 12 \mathrm{~nm}$ (Figure 5A). With the increase of mAlb concentration, the average particle sizes of the nanoparticles were $190.1 \pm 9.5$ and $170.5 \pm 8.5 \mathrm{~nm}$, respectively (Figure 5B and $\mathrm{C}$ ), and the particle size was generally uniform.

\section{Transmission electron microscopy (TEM)}

In addition to laser scattering, TEM was also used to record the shape and size of the particles. According to the procedure, TEM of the different systems were recorded (Figure 6). The catalytic activity of the blank system without mAlb was weak, so the reaction of $\mathrm{H}_{2} \mathrm{O}_{2}-\mathrm{HAuCl}_{4}$ was slow and there were rare big particles in the system (Figure 6A). When mAlb was added, it reacted specifically with the Ab to form free GONR6 and more nanoparticles were produced due to the restoration of GONR6 catalysis (Figure 6B). For the lower oxidation degree of GONR2, the catalytic effect was weaker and the AuNPs produced by the reaction were less. GONR2 with low oxidation degree contained a small amount of nanobelts. GONR6 solution with higher oxidation degree showed good catalytic activity, and the reaction resulted in more nanoparticles with comparatively more uniform particle size.

\section{Optimization of analytical conditions}

The analytical conditions of $\mathrm{HAuCl}_{4}-\mathrm{H}_{2} \mathrm{O}_{2}$-GONR6-AbmAlb system were optimized (Figure $\mathrm{S} 5$ ). The results showed that $\Delta \mathrm{I}_{1,615 \mathrm{~cm}^{-1}}$ reached the maximum at $1.84 \mathrm{ng} / \mathrm{mL}$ of GONR6. When the concentration of Ab was $3.3 \mathrm{ng} / \mathrm{mL}$, $\Delta \mathrm{I}_{1,615 \mathrm{~cm}^{-1}}$ reached the maximum. When the concentration of $\mathrm{H}_{2} \mathrm{O}_{2}$ was $2 \mathrm{mmol} / \mathrm{L}, \Delta \mathrm{I}_{1,615 \mathrm{~cm}^{-1}}$ was maximum. When the $\mathrm{HAuCl}_{4}$ concentration was $0.152 \mathrm{mmol} / \mathrm{L}, \Delta \mathrm{I}_{1,615 \mathrm{~cm}^{-1}}$ reached the maximum, and so $0.152 \mathrm{mmoL} / \mathrm{L} \mathrm{HAuCl}_{4}$ was selected. The $\mathrm{HCl}$ concentration was optimized too, and $0.11 \mathrm{mmol} / \mathrm{L}$ $\mathrm{HCl}$ was selected. Under the chosen conditions at $60^{\circ} \mathrm{C}$ water bath, the reaction time of 10 minutes was good. The
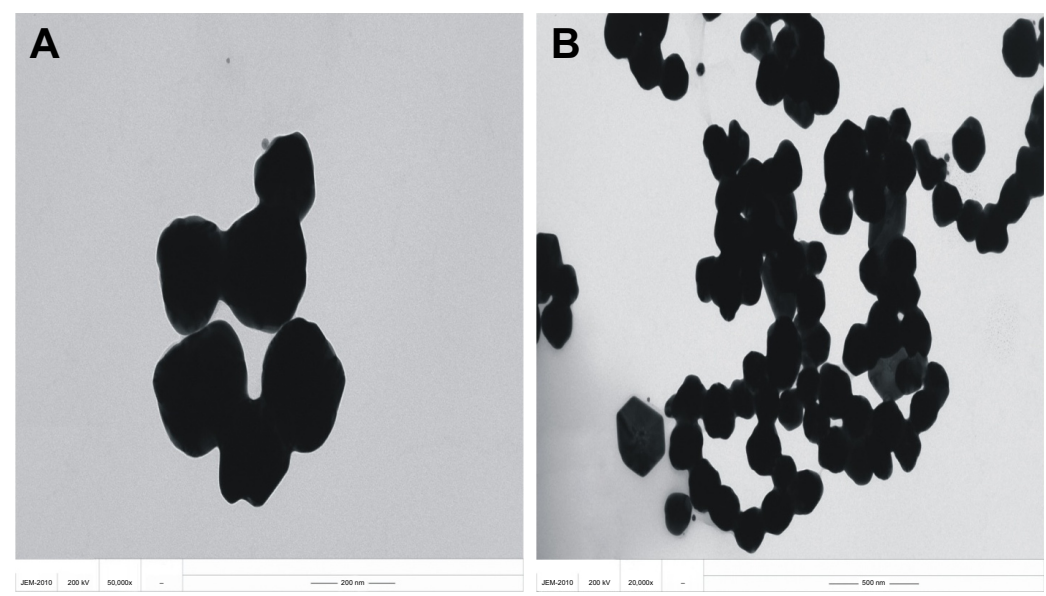

Figure 6 TEM of the analytical system.

Notes: (A) $0.21 \mathrm{mmol} / \mathrm{L} \mathrm{HAuCl}_{4}+0.006 \% \mathrm{H}_{2} \mathrm{O}_{2}+1.84 \mathrm{ng} / \mathrm{mL} \mathrm{GONR6}+0.1 \mathrm{mmol} / \mathrm{L} \mathrm{HCl}+3.3 \times 10^{-7} \mathrm{~mol} / \mathrm{L} \mathrm{VBB}+3.3 \mathrm{ng} / \mathrm{mL} \mathrm{Ab} ;(\mathbf{B}) \mathrm{A}+2.62 \mathrm{ng} / \mathrm{mL} \mathrm{mAlb}$. Abbreviations: TEM, transmission electron microscopy; GONR, graphene oxide nanoribbon; VBB, Victoria blue $B$. 
Table 2 Analysis feature of the SERS system

\begin{tabular}{lllll}
\hline GONR system & LR $(\mathbf{n g} / \mathbf{m L})$ & Linear equation & Coefficient & DL $(\mathbf{n g} / \mathbf{m L})$ \\
\hline GONRI & $0.33-6.6$ & $\Delta \mathrm{I}_{1,615 \mathrm{~cm}^{-1}}=107.6 \mathrm{C}+159.0$ & 0.9016 & 0.1 \\
GONR2 & $0.33-3.2$ & $\Delta \mathrm{I}_{\mathrm{l}, 615 \mathrm{~cm}^{-1}}=108.2 \mathrm{C}+40.9$ & 0.9586 & 0.1 \\
GONR3 & $0.33-3.2$ & $\Delta \mathrm{I}_{1,615 \mathrm{~cm}^{-1}}=380.6 \mathrm{C}+70.4$ & 0.9805 & 0.1 \\
GONR4 & $0.33-3.2$ & $\Delta \mathrm{I}_{\mathrm{l}, 615 \mathrm{~cm}^{-1}}=276.6 \mathrm{C}+80.0$ & 0.9699 & 0.1 \\
GONR5 & $0.24-3.2$ & $\Delta_{\mathrm{l}, 615 \mathrm{~cm}^{-1}}=398.6 \mathrm{C}-55.7$ & 0.9821 & 0.1 \\
GONR6 & $0.065-2.6$ & $\Delta \mathrm{I}_{1,615 \mathrm{~cm}^{-1}}=914.2 \mathrm{C}+20.0$ & 0.9874 & 0.02 \\
GONR7 & $0.13-2.6$ & $\Delta \mathrm{I}_{1,615 \mathrm{~cm}^{-1}}=558.4 \mathrm{C}+109.0$ & 0.9317 & 0.04 \\
GONR8 & $0.13-2.6$ & $\Delta \mathrm{I}_{\mathrm{l}, 615 \mathrm{~cm}^{-1}}=311.1 \mathrm{C}+71.1$ & 0.978 & 0.04 \\
\hline
\end{tabular}

Abbreviations: LR, linear range; DL, detection limit; GONR, graphene oxide nanoribbon.

probe concentration was optimized, and $0.33 \mu \mathrm{mol} / \mathrm{L} \mathrm{VBB}$ was selected.

\section{Working curve}

According to the procedure, the working curves of different SERS systems were drawn. For the GONR6 system, which was the most sensitive, the concentration of mAlb in the LR of $0.065-2.6 \mathrm{ng} / \mathrm{mL}$ has a good linear relationship with the $\Delta \mathrm{I}_{1,615 \mathrm{~cm}^{-1}}$, with the DL of $0.02 \mathrm{ng} / \mathrm{mL}$. By comparing three analytical techniques of SERS/RRS/Abs (Tables 2, $\underline{\mathrm{S} 1}$, and $\underline{\text { S2) }}$, the SERS method of GONR6 system had the highest slope (914.19), which shows that it has the highest sensitivity because of being strongest catalytic amplification, so it was selected to measure mAlb. Compared with the reported mAlb analysis method (Table S3) ${ }^{31-35,37-39}$ this method is highly sensitive and easy to operate, and it is one of the best methods for detecting mAlb.

\section{Interference effects}

The effects of coexisting substances in $\mathrm{HAuCl}_{4}-\mathrm{H}_{2} \mathrm{O}_{2}-$ GONR6-Ab-mAlb system on the determination of $10 \mathrm{ng} / \mathrm{mL}$ $\mathrm{mAlb}$ were investigated. The results showed that 100 times of $\mathrm{K}^{+}, \mathrm{Zn}^{2+}, \mathrm{Ca}^{2+}, \mathrm{S}_{2} \mathrm{O}_{3}{ }^{2-}, \mathrm{SO}_{3}{ }^{2-}, \mathrm{NO}_{2}{ }^{-}, \mathrm{CO}_{3}{ }^{2-}$, tyrosine, lysine, and phenylalanine; 50 times of $\mathrm{Cu}^{2+}, \mathrm{Mg}^{2+}$, tryptophan, and glutamic acid; and 10 times of $\mathrm{Fe}^{3+}$ and cysteine did not interfere with the determination in the relative error range of no more than $\pm 10.0 \%$, and the method has good selectivity.

\section{Sample analysis}

Five fresh urine samples including two from diabetic patients were obtained from the Yanshan District People's Hospital of Guilin City, and the samples were detected according to the experimental procedures. Then, different standard mAlb solution was added and detected. The results (Table S4) showed that the relative SD was between $0.49 \%$ and $2.28 \%$, and the recoveries were between $96.9 \%$ and $109.8 \%$.

\section{Conclusion}

The as-prepared GONR has strong catalytic effect on $\mathrm{HAuCl}_{4}-\mathrm{H}_{2} \mathrm{O}_{2}$ nanoreaction to form AuNPs with nanoplasmon effect such as SERS, RRS, and Abs, and Ab could adsorbed on the surface of GONR, which blocks the redox electron transfer of $\mathrm{HAuCl}_{4}$ and $\mathrm{H}_{2} \mathrm{O}_{2}$ to inhibit its catalytic action. Experiments show that $\mathrm{mAlb}$ enhances the signals of $\mathrm{Ab}$ GONR-HAuCl $-\mathrm{H}_{2} \mathrm{O}_{2}$ nanoanalytical system. Based on this principle, an immunoregulation gold nanoplasmon method for the rapid detection of $\mathrm{mAlb}$ has been established, with simplicity, high selectivity, and sensitivity.

\section{Acknowledgment}

This work was supported by the National Natural Science Foundation of China (No 21767004, 21667006, 21465006, 21477025), the Key Laboratory of Ecology of Rare and Endangered Species and Environmental Protection (ERESEP2017Z09), and the University Key Laboratory of Karst Ecology and Environmental Change of Guangxi Province (YRHJ16Z009).

\section{Disclosure}

The authors report no conflicts of interest in this work.

\section{References}

1. Manea F, Houillon FB, Pasquato L, Scrimin P. Nanozymes: Gold-Nanoparticle-Based Transphosphorylation Catalysts. Angew Chem Int Ed. 2004;43(45):6165-6169.

2. Gao L, Zhuang J, Nie L, et al. Intrinsic peroxidase-like activity of ferromagnetic nanoparticles. Nat Nanotechnol. 2007;2(9):577-583.

3. Karakoti A, Singh S, Dowding JM, Seal S, Self WT. Redox-active radical scavenging nanomaterials. Chem Soc Rev. 2010;39(11):4422-4432.

4. Asuri P, Karajanagi SS, Dordick JS, Kane RS. Directed assembly of carbon nanotubes at liquid-liquid interfaces: nanoscale conveyors for interfacial biocatalysis. J Am Chem Soc. 2006;128(4):1046-1047. 
5. Luo YH, Tang ML, Wen GQ, Yin WQ, Jiang ZL, Liang AH. A sensitive hydride generation-nanogold spectrophotometric method for trace As(III). Adv Mat Res. 2013;749:495-498.

6. Qu F, Li T, Yang M. Colorimetric platform for visual detection of cancer biomarker based on intrinsic peroxidase activity of graphene oxide. Biosens Bioelectron. 2011;26(9):3927-3931.

7. He W, Liu Y, Yuan J, et al. Au@Pt nanostructures as oxidase and peroxidase mimetics for use in immunoassays. Biomaterials. 2011;32(4): $1139-1147$.

8. Liang A, Li C, Li D, Luo Y, Wen G, Jiang Z. A facile and sensitive peptide-modulating graphene oxide nanoribbon catalytic nanoplasmon analytical platform for human chorionic gonadotropin. Int $J$ Nanomedicine. 2017;12:8725-8734.

9. Ye D, Li H, Liang G, Luo J, et al. A three-dimensional hybrid of MnO2/ graphene/carbon nanotubes based sensor for determination of hydrogenperoxide in milk. Electrochim Acta. 2013;109(11):195-200.

10. Liu X, Peng Y, Qu X, Ai S, Han R, Zhu X. Multi-walled carbon nanotube-chitosan/poly(amidoamine)/DNA nanocomposite modified gold electrode for determination of dopamine and uric acid under coexistence of ascorbic acid. J Electroanal Chem. 2011;654(1-2):72-78.

11. Cui R, Han Z, Zhu JJ. Helical carbon nanotubes: intrinsic peroxidase catalytic activity and its application for biocatalysis and biosensing. Chemistry. 2011;17(34):9377-9384.

12. Zhang Y, Xia Z, Liu H, Yang M, Lin L, Li Q. Hemin-graphene oxidepristine carbon nanotubes complexes with intrinsic peroxidase-like activity for the detection of $\mathrm{H} 2 \mathrm{O} 2$ and simultaneous determination for Trp, AA, DA, and UA. Sens Actuators B Chem. 2013;188:496-501.

13. Zhang TT. Preparation of graphene oxide nanoribbon bioelectrochemical sensor and detection of amino acids. Chin J Biochem Pharm. 2017;37:58-61.

14. Dong X, Long Q, Wang J, et al. A graphene nanoribbon network and its biosensing application. Nanoscale. 2011;3(12):5156-5160.

15. Zhu G, Yi Y, Han Z, Wang K, Wu X. Sensitive electrochemical sensing for polycyclic aromatic amines based on a novel core-shell multiwalled carbon nanotubes@graphene oxide nanoribbons heterostructure.Anal Chim Acta. 2014;845:30-37.

16. Mcnay G, Eustace D, Smith WE, Faulds K, Graham D. Surfaceenhanced Raman scattering (SERS) and surface-enhanced resonance Raman scattering (SERRS): a review of applications. Appl Spectrosc. 2011;65(8):825-837.

17. Javier EL, Ronei JP. A portable SERS method for the determination of uric acid using a paper-based substrate and multivariate curve resolution. Analyst. 1966;2016:141

18. Wang X, Jiang C, Qin Y, et al. SERS spectral study of $\mathrm{HAuCl}_{4}$-cysteine nanocatalytic reaction and its application for detection of heparin sodium with label-free VB4r molecular probe. Sci Rep. 2017;7:45979.

19. Frost MS, Dempsey MJ, Whitehead DE. Highly sensitive SERS detection of $\mathrm{Pb}^{2+}$ ions in aqueous media using citrate functionalised gold nanoparticles. Sens Actuators B Chem. 2015;221:1003-1008.

20. Gao F, Lei J, Ju H. Label-free surface-enhanced Raman spectroscopy for sensitive DNA detection by DNA-mediated silver nanoparticle growth. Anal Chem. 2013;85(24):11788-11793.

21. Wang Z, Zong S, Wu L, Zhu D, Cui Y. SERS-activated platforms for immunoassay: Probes, encoding methods, and applications. Chem Rev. 2017;117(12):7910-7963.

International Journal of Nanomedicine

\section{Publish your work in this journal}

The International Journal of Nanomedicine is an international, peerreviewed journal focusing on the application of nanotechnology in diagnostics, therapeutics, and drug delivery systems throughout the biomedical field. This journal is indexed on PubMed Central, MedLine, CAS, SciSearch ${ }^{\circledR}$, Current Contents ${ }^{\circledR} /$ Clinical Medicine,
22. Haisch C. Raman-based microarray readout: a review. Anal Bioanal Chem. 2016;408(17):4535-4545.

23. Granger JH, Schlotter NE, Crawford AC, Porter MD. Prospects for point-of-care pathogen diagnostics using surface-enhanced Raman scattering (SERS). Chem Soc Rev. 2016;45(14):3865-3882.

24. Wang Z, Feng L, Xiao D, et al. A silver nanoislands on silica spheres platform: enriching trace amounts of analytes for ultrasensitive and reproducible SERS detection. Nanoscale. 2017;9(43):16749-16754.

25. Laing S, Gracie K, Faulds K. Multiplex in vitro detection using SERS. Chem Soc Rev. 2016;45(7):1901.

26. Ma L, Wen G, Ye L, et al. SERS quantitative detection of trace human chorionic gonadotropin using a label-free Victoria blue B as probe in the aggregated immunonanogold sol substrate. Luminescence. 2015; 30(6):790-797.

27. She $\mathrm{P}, \mathrm{Chu} \mathrm{Y}$, Liu C, et al. A competitive immunoassay for ultrasensitive detection of $\mathrm{Hg}^{2+}$ in water, human serum and urine samples using immunochromatographic test based on surface-enhanced Raman scattering. Anal Chim Acta. 2016;906:139-147.

28. Toto RD. Microalbuminuria: definition, detection, and clinical significance. J Clin Hypertension. 2010;6(s11):2-7.

29. Shi BQ. Detection of microalbuminuria in the prevention and treatment of diabetic nephropathy. Pest Control. 2007;23:479-480.

30. Habudutra S. Clinical significance of urine microalbumin detection. World Latest Med Inform. 2016;15:66-68.

31. Tsai JZ, Chen CJ, Settu K, Lin YF, Chen CL, Liu JT. Screen-printed carbon electrode-based electrochemical immunosensor for rapid detection of microalbuminuria. Biosens Bioelectron. 2016;77:1175-1182.

32. Pan AP. Comparison of urinary microalbumin in patients with diabetes mellitus by immunoturbidimetry and radioimmunoassay and clinical application. Exper Lab Med. 2003;21:26.

33. Neuman RG, Cohen MP. Improved competitive enzyme-linked immunoassay (ELISA) for albuminuria. Clin Chim Acta. 1989;179(3): 229-237.

34. Wang YC, Chen RS. Comparison of urinary microalbumin assays. Chin $J$ Lab Med. 1995;15:266.

35. Horikoshi S, Okuda M, Nishimura E, et al. Usefulness of HPLC assay for early detection of microalbuminuria in chronic kidney disease. J Clin Lab Anal. 2013;27(4):333-338.

36. Liang A, Li C, Wang X, Luo Y, Wen G, Jiang Z. Immunocontrolling graphene oxide catalytic nanogold reaction and its application to SERS quantitative analysis. ACS Omega. 2017;2(10):7349-7358.

37. Ruhn PF, Taylor JD, Hage DS. Determination of urinary albumin using high-performance immunoaffinity chromatography and flow injection analysis. Anal Chem. 1994;66(23):4265-4271.

38. Beasley-Green A, Burris NM, Bunk DM, Phinney KW. Multiplexed LC-MS/MS assay for urine albumin. J Proteome Res. 2014;13(9): 3930-3939.

39. Laiwattanapaisal W, Kunanuvat U, Intharachuti W, Chinvongamorn C, Hannongbua S, Chailapakul O. Simple sequential injection analysis system for rapid determination of microalbuminuria. Talanta. 2009; 79(4):1104-1110
Journal Citation Reports/Science Edition, EMBase, Scopus and the Elsevier Bibliographic databases. The manuscript management system is completely online and includes a very quick and fair peer-review system, which is all easy to use. Visit http://www.dovepress.com/ testimonials.php to read real quotes from published authors. 